\title{
Activation of Cholinergic Anti-Inflammatory Pathway in Peripheral Immune Cells Involved in Therapeutic Actions of $\alpha$-Mangostin on Collagen-Induced Arthritis in Rats [Corrigendum]
}

Yin Q, Wu Y, Pan S, et al. Drug Des Devel Ther. 2020;14:1983-1993.
The correct Figure 1 is shown below. The authors apologize for this error.

The authors have advised the representative images for histological examination of the CIA and MG groups in Figure 1B, page 1987, are identical.
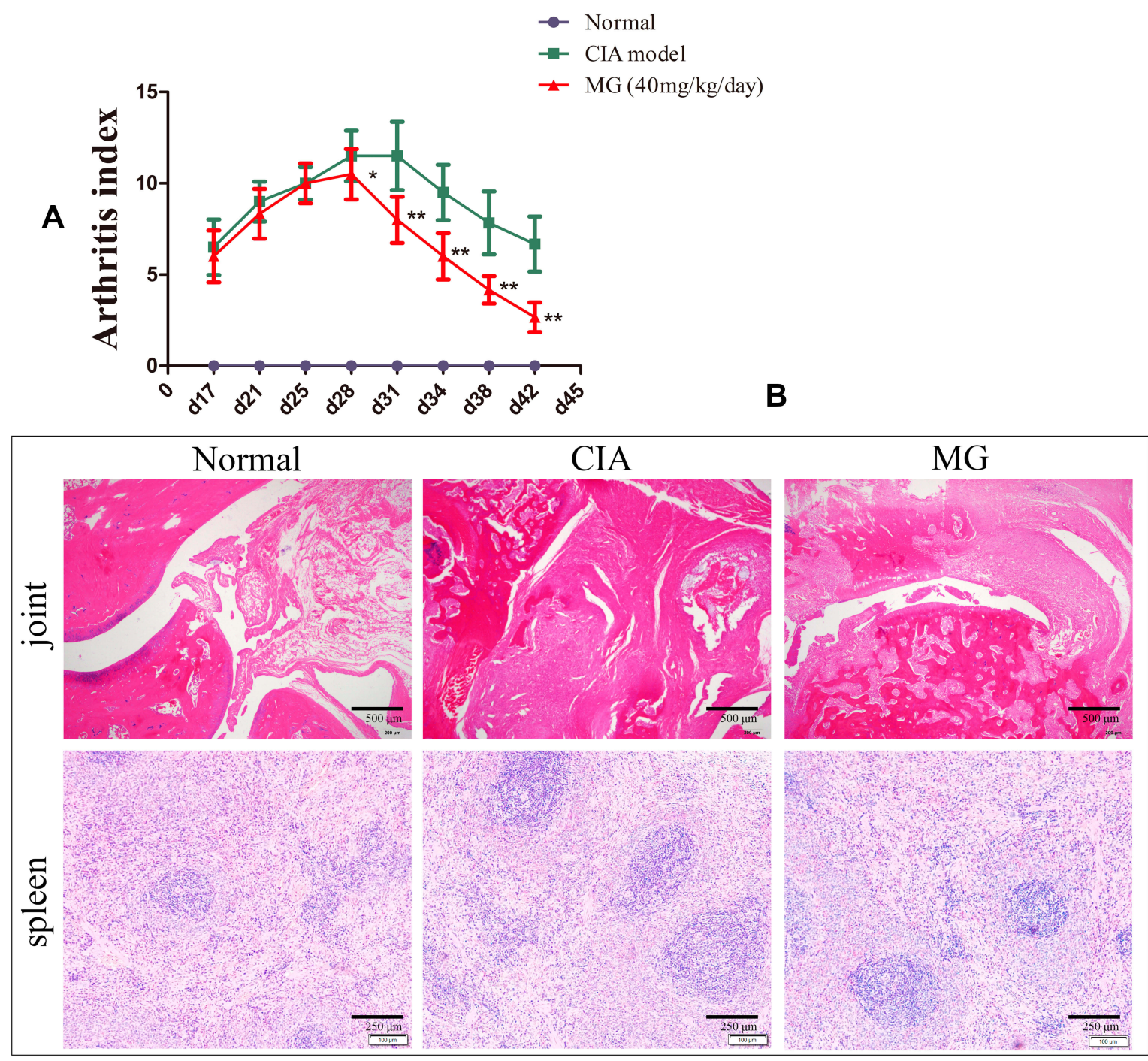

Figure I Continued. 


\section{C}

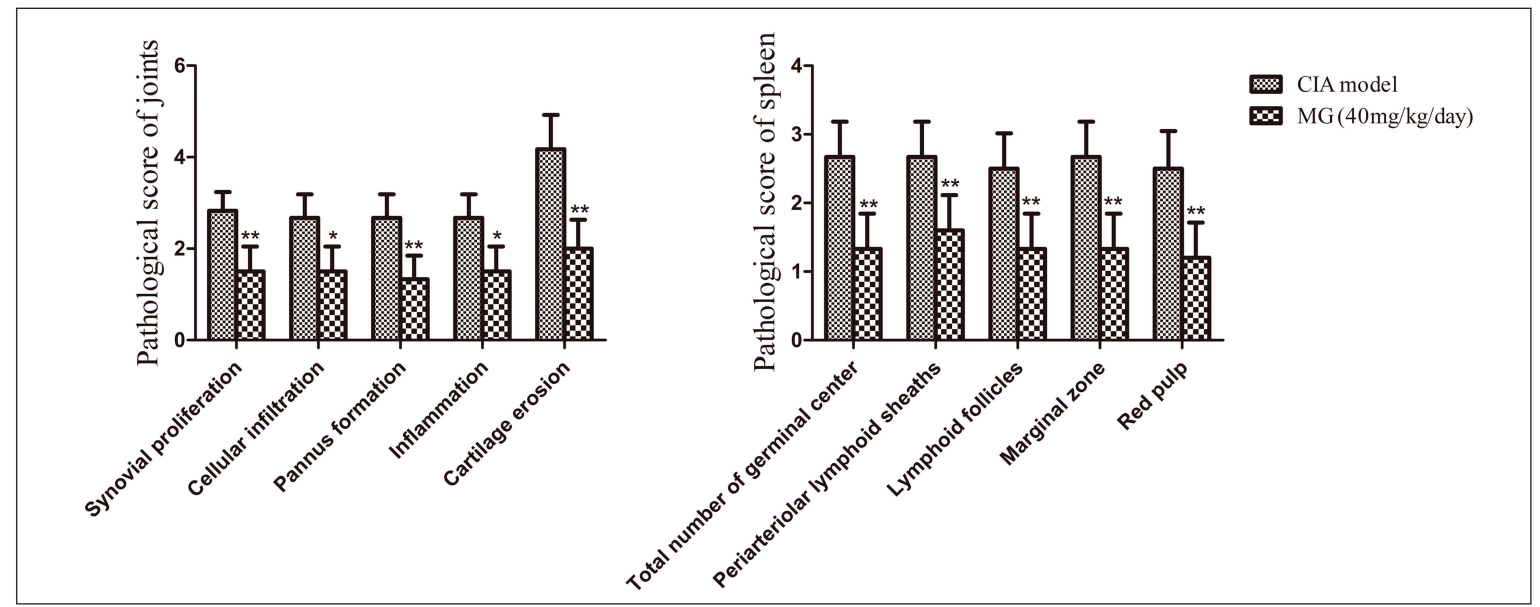

Figure I Therapeutic effects of MG on CIA rats. (A) Arthritis index changes in rats; (B) histological examination of joint and spleen; (C) histopathological scores of joint and spleen. Data are presented as mean $\pm S D(n=6)$. $* P<0.05$ and $* * P<0.01$ compared with CIA rats.

\section{Publish your work in this journal}

Drug Design, Development and Therapy is an international, peerreviewed open-access journal that spans the spectrum of drug design and development through to clinical applications. Clinical outcomes, patient safety, and programs for the development and effective, safe, and sustained use of medicines are a feature of the journal, which has also been accepted for indexing on PubMed Central. The manuscript management system is completely online and includes a very quick and fair peer-review system, which is all easy to use. Visit http://www. dovepress.com/testimonials.php to read real quotes from published authors. 